Article

\title{
Cross-Sector Social Partnerships for Social Change: The Roles of Non-Governmental Organizations
}

\author{
Xinya Yan ${ }^{1}$, Haiying Lin ${ }^{2, *}$ and Amelia Clarke ${ }^{3}$ (D) \\ 1 Local Economic Development Program, School of Environment, Enterprise, and Development (SEED), \\ University of Waterloo, 200 University Ave W. Waterloo, ON N2L 3G1, Canada; x3yan@uwaterloo.ca \\ 2 Management Department, College of Business, Northern Illinois University, DeKalb, IL 60115, USA \\ 3 School of Environment, Enterprise, and Development (SEED), University of Waterloo, 200 University Ave W, \\ Waterloo, ON N2L 3G1, Canada; Amelia.Clarke@uwaterloo.ca \\ * Correspondence: hlin2@niu.edu; Tel.: +1-815-753-6160
}

Received: 23 December 2017; Accepted: 13 February 2018; Published: 23 February 2018

\begin{abstract}
Complex social and environmental issues call for broader collaboration across different sectors so as to instigate transformative social change. While previous scholars have emphasized the role of non-governmental organizations (NGOs) in facilitating social change, they have not provided a nuanced assessment of NGOs' different roles. We use the Poverty and Employment Precarity in Southern Ontario (PEPSO) research partnership as a study case and explore NGO partners' different roles in a large cross-sector social partnership (CSSP). By interviewing 12 NGO partners and 4 non-NGO partners involved in the PEPSO research partnership, our research results show that NGOs primarily have 10 roles in a CSSP. They include enabling roles such as consultant, capacity builder, analyst, and funder; coordinating roles such as broker and communicator; and facilitating roles such as initiator, leader, advocate, and monitor. These roles allow NGOs to fulfil their duties to make substantial contributions to a CSSP.
\end{abstract}

Keywords: roles of non-governmental organizations; NGOs; cross-sector social partnerships; social change; sustainable development goals; SDG \#17; SDG \#8; broker; enabler; facilitator

\section{Introduction}

Despite the rapid economic and technological development, humanity faces numerous complex socioenvironmental issues such as poverty alleviation, resource degradation, and climate change $[1,2]$. The scale and complexity of these issues prompt organizations from different sectors to convene diverse cross-sector partners such as researchers and community advocates to explore innovative solutions that effectively address these problems [2-5]. The United Nations Global Sustainable Development Goal (SDG) \#17 in particular recognizes the role of partnerships in addressing sustainability issues [6,7]. Non-governmental organizations (NGOs) have become a key player in dealing with many economic, environmental, and social development issues [8]. They are playing an increasingly important role in initiating, convening, bridging, and coordinating different actors into a social change process that emphasizes equity, long-term security, sustainable community, and inclusive human development over time and space [9]. Nowadays, NGOs have played a major role for sustainable development at both national and international level and they also facilitate public and private sectors integrating sustainable development concerns into the decision-making process [8].

While extant cross-sector social partnerships (CSSPs) studies recognize that partner diversity, especially NGO involvement, may cause more proactive outcomes (e.g., [5]), we still have a limited understanding of NGOs' various roles in collaborative settings. While social innovation and sustainable community development have gradually gained public attention and are discussed globally [10], our understanding of how NGOs facilitate such social change processes via the formulation and 
implementation of CSSPs remains limited. In such a context, NGOs' specific roles in social partnerships that promote sustainability have gained increased attention among scholars and practitioners [8]. In this study, we aim to advance the CSSP scholarship by exploring the question: "what are the roles of NGOs in a cross-sector partnership setting?"

We explored this research question via an inductive approach, using a community-university research partnership — the Poverty and Employment Precarity in Southern Ontario (hereafter PEPSO) research partnership—as our study case. Precarious employment refers to "nonstable jobs" that lack benefits and security [11]. It is mainly characterized by increased insecurity in employment, reduced entitlement to ongoing work, low control of work scheduling, low remuneration, limited benefits, and few career advancement opportunities [12]. As a country with a large immigrant population and one that was impacted by the recent economic recession, Canada has precarious employment challenges. In such a context, the PEPSO partnership was formed in 2008 to convene 31 partners $(20$ of which are NGOs) to collectively address the pressing precarious employment problem in Ontario. PEPSO is an excellent example of a cross-sector partnership designed to address the UN Global Sustainable Development Goal (SDG) \#8 and its specific targets 8.5 and 8.6, which are focused on productive employment and decent work for all.

We built on this case and interviewed key players in PEPSO partnerships to understand NGOs' different roles in PEPSO. By comparing inductive coding of interview transcripts and deductive coding from the literature, we advance the CSSP scholarship by developing and empirically testing a framework of NGOs' roles in large CSSPs. We also further our understanding to help implement SDG $\# 8$ and the roles of NGOs in large sustainability partnerships (SDG \#17).

\section{Literature Review: NGOs' Roles in CSSPs}

NGOs are motivated to become involved in CSSPs so as to gain access to partner resources and to leverage CSSP platforms to facilitate large-scale social change and innovation [13]. While NGOs play different roles in different CSSPs, and their interactions with other sectors in CSSPs vary over time and in different fields of service [14], we find three primary categories: the first, dominant category relates to NGOs' enabling roles, with a focus on service provision, consulting, and capacity development. The other two categories specifically explain the coordinating roles that NGOs have developed in bridging different parties in CSSPs and their facilitating roles in initiating, leading, and advocating social change.

\subsection{Enabling Roles: Service Provider, Capacity Builder, and Consultant}

Through CSSP platforms, a vibrant nonprofit sector can provide essential services and can help to satisfy the needs of citizens, so that they can benefit from economic and social aspects to make communities a better place [8]. Partnerships between NGOs, governments, and universities have emerged as an increasingly popular approach in many public management and social fields [15-17]. To some extent, NGOs in this context usually act as assistance providers to educate and train volunteers in order to support a whole community to achieve specific goals. In various contexts, "nonprofits have served as privately supported supplementary service providers of public goods, and as complementary partners with government and universities in public service provisions" [14] (p. 38).

These roles of NGOs are not restricted to service delivery, such as the reduction of global poverty, but also involve building CSSP partners' capacities. Over time, NGOs have recognized the importance of expanding partnerships with other CSSP partners, especially private sector ones, as a strategic means to diversify their own resource base and simultaneously strengthen partners' capacity to become responsible 'citizens' [18]. NGOs used to lobby for corporate change through advocacy. Nowadays, NGOs increasingly play enabling roles for CSSP partners (e.g., corporations, research institutions): they facilitate the combination of diverse resources and expertise from cross-sector partners [19-21] and the conduction of collective learning in solving social problems $[8,13,22]$. Via education and facilitation of knowledge sharing in a CSSP platform, NGOs help other cross-sectoral partners in CSSPs 
to develop their capacities for environmental and social improvements. For instance, in the case of the partnerships of Tembec-WWF and Norske Canada-WWF, the World Wide Fund for Nature (WWF) helped to conduct consumer surveys, provided companies with advice, expertise, and feedback on their progress, and facilitated companies' innovative product development [23].

In addition, NGOs can also have a consultative role in CSSPs, providing support and documentation and disseminating information and expertise in the CSSPs [20]. They produce knowledge through research, disseminate innovative knowledge as a public good, which influences public vision and policy agendas [24]. In other instances of CSSPs, NGOs empower local communities by providing credit (e.g., microfinance), building community capacity [25], and creating job and income opportunities. These roles effectively reduce poverty $[25,26]$ and motivate communities to become involved in projects that improve people's quality of life [25] and help communities to become more self-reliant [25].

\subsection{Coordinating Roles: Bridger (Broker) and Mediator}

Many NGOs have sophisticated understandings of the socioenvironmental problems. They are boundary spanners that bridge different mindsets, missions, roles, strategies, and practices of diverse partners in a CSSP setting for social change [27,28]. As bridging organizations, these NGOs work to span the gap between large-scale institutions and individuals [29]. This bridging role is critical for basic service provision, as NGOs can help provide and deliver better government services to the right recipients and in the right places [24]. During this process, NGOs usually are brokers (bridgers), developing relationships and networks with multiple stakeholders and providing knowledge and linkage sources $[27,30,31]$. These NGOs integrate diverse logics and viewpoints among cross-sectoral partners and act as knowledgeable intermediaries [32] that integrate various resources and competencies to develop effective strategies to deal with social and environmental problems.

During the collaboration process, CSSP partners may have conflicts due to the fact that these partners are from diverse sectors with different missions, interests, and agendas [18]. In these circumstances, as NGOs can retain independence among a range of stakeholders, they usually act as a strategic mediator to restore a balance of power in negotiating and cooperating with different stakeholders to solve mistrust, different traditions, and logistical problems [30,33]. Based on a study by Martin (2012) on NGOs' roles in solving problems of precarious work, the author indicated that NGOs have emerged as labor market intermediaries in CSSPs. These organizations stand at the frontlines of responding to social concerns as well as collaborating with government enforcement agencies to educate workers on protecting their rights and filing claims against employers [34]. When there are disputes between employers and workers, these NGOs may act as intermediaries to mitigate conflicts and may collaborate with private sectors to strengthen workers' work skills and experience [34].

Overall, in brokering social change, an NGO usually acts as a bridge in connecting governments, private sectors, and research institutions. "Unlike mediators, bridgers enter partnerships to further their own ends and to serve as links among domain stakeholders" [35] (p. 461). In other instances when conflict arises in CSSPs because of partners' different visions and priorities, NGOs may act as a third party and may mediate between the inside and outside political forces and areas to address potential relational issues that may cause a CSSP to fail.

\subsection{Change Facilitating Roles: Initiator, Convener, Advocate, Leader, and Innovator}

The third NGO role category relates to an NGO's facilitation of the social change process as an initiator, convener, advocate, leader, and innovator so as to stimulate social innovation.

An increasing number of NGOs show a willingness to be an initiator in social change and "contribute to sustainable development through their partnerships with key stakeholders in serving the needs of individuals and communities" [19]. In this process, NGOs may play a convener role "to identify and bring all the legitimate stakeholders to the table" $[4,36,37]$. This NGO role in the CSSP 
formation stage is critical, since not all organizations want to partner with other sectors because of the inherent complexity that might result in unstable and strategically precarious relationships.

After CSSP formation, NGOs may advocate social change to the other CSSP partners. NGOs' advocacy role in this context can be defined as an "attempt to influence the decisions of any institutional elite on behalf of a collective interest" [24] (p. 65). According to Najam [38], a large number of NGOs act as policy entrepreneurs in a collaborative setting and seek to influence and change policy in innovative ways. Through knowledge sharing and delivering effective services in CSSPs, NGOs gradually build their legitimacy within local communities, which helps to create a platform for policy advocacy [24].

NGO advocacy not only directly influences governments, it is also increasingly concerned with influencing private sectors in a CSSP setting. They may act as an advocator and play an essential role in raising public awareness, enhancing political support, and orchestrating partnerships that influence change in the private sector [24,39]. For instance, by partnering with a wide range of communities that included private sectors, Greenpeace and Friends of the Earth conducted an anti-genetically modified food campaign in the 1990s [39]. This campaign garnered much attention and effectively mobilized the public opinion against genetically modified food [24]. NGOs' collaboration with internal and external organizations can ensure a successful advocacy campaign [40].

"NGOs not only act as advocates and adversaries in the process of public policy formulation and implementation" [14] (p. 38), but may also become the lead organization in a CSSP to facilitate collaborative problem solving [36]. During this process, an NGO can also bring about change as an innovator and can apply new solutions to development problems [41,42]. In this role, NGOs may be involved in developing new technologies or seeking to adapt existing technologies to strengthen their innovation abilities [24]. As innovators, these NGOs are proactive in exploring new solutions to existing complex social environmental problems [41] and in generating new policies, standards, or mechanisms.

Table 1 summarizes the literature that explains NGOs' different roles in CSSPs.

Table 1. A Summary of the Literature on non-governmental organizations (NGOs)' Different Roles in CSSP.

\begin{tabular}{|c|c|c|c|}
\hline & Roles & Related Theory Codes and Citation & Literature \\
\hline \multirow{3}{*}{$\begin{array}{l}\text { Enabling } \\
\text { roles }\end{array}$} & $\begin{array}{l}\text { Service } \\
\text { provider }\end{array}$ & $\begin{array}{l}\text { Provide communities with services; support supplementary } \\
\text { services for public goods; educate and train volunteers to help } \\
\text { communities achieve goals }\end{array}$ & {$[20]$} \\
\hline & Consultant & $\begin{array}{l}\text { Take the consultative role to provide support and } \\
\text { documentation and to disseminate information and expertise } \\
\text { in the collaboration }\end{array}$ & [20] \\
\hline & $\begin{array}{l}\text { Capacity } \\
\text { builder }\end{array}$ & $\begin{array}{l}\text { Develop communities' capacities through education and } \\
\text { training or empowerment via credit provision }\end{array}$ & [25] \\
\hline \multirow{2}{*}{$\begin{array}{l}\text { Coordinating } \\
\text { roles }\end{array}$} & Bridger & $\begin{array}{l}\text { Bridge gaps between the public sector and private sectors, } \\
\text { between institutions and individuals; connect internal and } \\
\text { external groups; connect and coordinate different key } \\
\text { stakeholders including government and businesses. }\end{array}$ & $\begin{array}{l}{[24]} \\
{[30]} \\
{[20]} \\
{[19]} \\
{[14]}\end{array}$ \\
\hline & Mediator & $\begin{array}{l}\text { Balance power in negotiating and cooperating with } \\
\text { stakeholders; take the mediator role for both internal and } \\
\text { external political areas }\end{array}$ & [16] \\
\hline
\end{tabular}


Table 1. Cont.

\begin{tabular}{llll}
\hline & Roles & Related Theory Codes and Citation & Literature \\
\hline & Initiator & $\begin{array}{l}\text { Initiate social change through partnering with key } \\
\text { stakeholders }\end{array}$ & {$[19]$} \\
\cline { 2 - 4 } & Convener & $\begin{array}{l}\text { Convene processes in building and sustaining } \\
\text { multi-stakeholder networks to jointly tackle complex } \\
\text { problems }\end{array}$ & {$[37]$} \\
\cline { 2 - 4 } $\begin{array}{l}\text { Facilitating } \\
\text { roles }\end{array}$ & Advocate & $\begin{array}{l}\text { Act as advocates and adversaries in the process of public } \\
\text { policy formulation and implementation; facilitate community } \\
\text { and political awareness; advocacy campaigns; influence and } \\
\text { bring about social change }\end{array}$ & {$[41]$} \\
& Leader & The lead organization in CSSPs & {$[3]$} \\
\cline { 2 - 4 } & Innovator & Apply new solutions to solve social problems & {$[41]$} \\
\hline
\end{tabular}

\section{Case Description: The PEPSO Research Partnership}

Owing to the rapid globalization, many communities face increasingly complex challenges with multiple social, economic, and cultural dimensions. Many challenges are local and regional. Precarious employment has particularly caught the attention of Canada's government in the past two decades [11]. According to a new study of Canada's labor market, only $60 \%$ of adult workers in the Greater Toronto and Hamilton areas have permanent jobs; the other $40 \%$ fall into the precarious employment [44] category. In 2007, the United Way Toronto (UWT) published the report Losing Ground: The Persistent Growth of Family Poverty in Canada's Largest Cities. Job precarity has become increasingly serious in Toronto, which is likely to result in a series of social problems, including homelessness, local economic stagnation, and lack of community cohesion [45,46]. Hamilton, Peel, and York (2013)'s work showed similar findings. According to United Nations Sustainable Development Knowledge Platform, the Sustainable Development Goal \#8 is focused on promoting "sustained, inclusive and sustainable economic growth, full and productive employment and decent work for all" [7] (p. 1). Therefore, reducing the unemployment rate, improving people's quality of life, and eliminating the employment precarity would have profound significance for developing a sustainable society. With increasing media coverage of employment precarity, many NGOs, facing such social issues daily, were concerned about the trends of these social problems and sought to take the lead in influencing policy and practical change. In 2008, the United Way Toronto decided to address the increasing problem of poverty and employment precarity. Owing to the complexity and resource limitations in conducting research on poverty and employment precarity, the United Way Toronto needed help from other organizations, especially universities, in helping communities to build capacity. It was in this context that the United Way Toronto initiated the formation of the community-university research group-the Precarious Employment Research Group (PERG) [47]. PERG took the intellectual lead in developing the PEPSO community-university research partnership [48]. This partnership was based on equal collaboration between community organizations and at least one post-secondary institution [49].

This cross-sector social partnership between academia and NGOs aimed to assess precarious employment's impacts on individuals, households, and communities [48]. All the partners in the partnership collaborated to gather data on precarious employment trends and to encourage policy debate [45]. Through a process of ongoing collaboration and mutual learning, as well as research innovation, new knowledge and expertise could be shared in this partnership setting. All partners jointly defined one or more academic disciplines to target on one or more research themes [49]. Based on the governance structure of such a CSSP, a researcher from an academic institution or a community organization staff member can lead or co-lead the partnership to achieve its research goals [50].

By addressing precarity and related social issues in the Greater Toronto and Hamilton areas, such a CSSP satisfies the research needs identified by community agencies to work towards encouraging 
policy change. Currently, more than 15 community partners across Southern Ontario and university researchers from various Canadian and foreign universities have been involved in the PEPSO research partnership to study precarious employment's impacts on communities and to advocate policy change so as to improve people's quality of life [51], and the number of NGO partners in this community-university partnership has continued to grow [45]. The United Way Toronto took the overall lead in the partnership, with McMaster University in a significant co-leadership role.

Through identifying the roles of NGOs in CSSPs in PEPSO research partnership, this paper directly contributes to further understanding the means of implementing global sustainable development goals.

\section{Methodology}

This study explores NGOs' roles in a CSSP using a qualitative case study design, generating theory through an inductive approach $[14,52]$. We interviewed key players in the CSSP case to gather related information about NGOs' roles in this CSSP.

\subsection{Case Selection}

The PEPSO research partnership was selected because it met our criteria: (1) it is a large CSSP; (2) twenty NGOs are involved; (3) these NGOs are diverse in terms of sizes and operation scales; (4) the partnership represents a typical CSSP that involves partners from two different sectors (community and university); (5) the partnership focuses on precarious social problems such as employment and/or poverty reduction; (6) information about the case was accessible.

According to the partnership information updated on PEPSO's website, 20 NGO partners are engaged in this community-university research partnership. Most, but not all, of these NGO partners are locally based and have similar missions, values, and working areas that concentrate on poverty alleviation and employment services. Depending on an organization's size, the funding and human capacities are different for each NGO partner. Thus, this community-university research partnership provides an apt platform for exploring varied NGO roles in large CSSPs that address complex social issues.

\subsection{Data Collection}

Since we focused on finding out the roles of NGOs in a CSSP on poverty and employment precarity, we collected primary data via semi-structured interviews $[14,53]$. The names of the potential interviewees were found by researching PEPSO report name lists and researching NGO partner websites. One interview participant was selected from each NGO as a contact because of their intimate knowledge of the community-university partnership. We formulated 14 questions for non-profit partners (Appendix A) and 13 for government and university partners (Appendix B); these were vetted by the academic advisors. We sent an interview invitation letter to each NGO involved in the partnership, but because of mixed willingness and time management, 12 NGOs out of 20 and 4 non-NGO partners in the partnership were willing to participate in the phone interviews.

Table 2 shows the organizations (including the NGOs, governmental organizations, and universities that were involved as community partners) in PEPSO that we interviewed.

We conducted 16 semi-structured phone interviews with staff members of NGOs and non-NGOs involved in the PEPSO partnership. Each interview lasted about 15 to $30 \mathrm{~min}$. We recorded and transcribed all interviews. 
Table 2. Interview Participants.

\begin{tabular}{c}
\hline Organization (NGO and Non-NGO) \\
\hline Toronto Workforce Innovation Group \\
SPRC (Social Planning Research Council of Hamilton) \\
Wood Green Community Services \\
United Way of Peel Region \\
Wellesley Institute \\
United Way Toronto \& York Region \\
COSTI \\
Former employee, Wellesley Institute \\
JVS Toronto \\
Social Planning Toronto \\
Worker Action Centre \\
Access Partnership \\
Ryerson University \\
McMaster University \\
City of Toronto (Government) \\
Region of Peel (Government)
\end{tabular}

\subsection{Data Analysis}

The data analysis started with deductive coding, followed by a round of inductive coding [53]. We made margin notes on keywords while reading the transcripts. We combined contexts from the transcripts for each code into one document, keeping the NGO and non-NGO interviewees separate. We reviewed the transcribed interviews and analyzed the codes twice to ensure that there were no duplicate ideas and codes. We further grouped the codes into categories so that we could identify larger concepts in the interviews. The lead researcher's handwritten notes were considered so as to obtain further insights for theory development [53].

A second coder then used the deductive code list and transcripts to code independently [14]. Following the deductive coding round, this coder also completed an inductive coding round. The second coder's results were then compared to those of the first coder to confirm inter-coder reliability. Inconsistencies were examined and discussed by all the co-authors until agreement was reached. Variances in the terms chosen for the inductive coding were discussed by the team in relation to the literature until the final list was created.

\section{Empirical Findings}

\subsection{NGOs in the PEPSO Research Partnership}

According to the PEPSO website, there are 20 NGO partners in this community-university research partnership, and all are located in the Greater Toronto and Hamilton areas, including the City of Toronto, the York Region, the Peel Region, and the City of Hamilton.

In terms of scale, these NGO partners can be divided into three categories: local, national, and global nonprofits. Since the PEPSO project mainly addresses poverty and employment precarity issues in Southern Ontario, $90 \%$ of these NGO partners are locally based. The number of staff and volunteers in each non-profit community partner differ, depending on organization size and the amount of funding support.

However, there are common themes around these NGOs in terms of their mandate, mission, and the work they do. Because these NGO partners are members of the PEPSO research partnership, their core working areas focus on poverty alleviation, health equity, social and economic justice, and employment services. By undertaking ground breaking research and establishing powerful partnerships, the NGO partners want to make communities safer, more caring, and sustainable. 


\subsection{NGOs' Roles in a CSSP on Poverty and Employment Precarity}

We asked interviewees from the NGO sector and other sectors in the PEPSO research partnership about what roles NGOs take in this community-university research partnership and what contributions they make to the partnership. In the following section we present the answers from two interview groups, along with our interpretations.

From the perspectives of the NGO and non-NGO sectors, the NGOs' roles in a communityuniversity research alliance are classified into eight categories. Table 3 shows these roles and presents detailed descriptions.

Table 3. NGO Roles from Interviews.

\begin{tabular}{ll}
\hline Roles & Related Comments \\
\hline Advocate & $\begin{array}{l}\text { Impact the lives of community members; make people aware; provide a voice for the } \\
\text { community; raise awareness; educate the public; exercise influence so as to change policies } \\
\text { and practices; connect research to policy }\end{array}$ \\
\hline Initiator & Take initiative in research; encourage project initiation; engage from initiation to execution \\
\hline Leader & Lead the case study; co-lead the case study; co-lead the research \\
\hline Analyst & $\begin{array}{l}\text { Shape the project; do the case study; review and publish the results; write proposals; do } \\
\text { data analysis; design the survey; view graphs; research design; interpret results; frame and } \\
\text { shape the report; conduct interviews }\end{array}$ \\
\hline Broker (Bridger) & $\begin{array}{l}\text { Reach out to community members; reach out to service providers; connect community } \\
\text { agencies and clients; bring partners together; contact other experts to strengthen the } \\
\text { partnership }\end{array}$ \\
\hline Communicator & $\begin{array}{l}\text { Work on key strategic communication across different partners; enhance partnership } \\
\text { communication by reporting the findings and disseminating the message of the project to } \\
\text { partners and to the public }\end{array}$ \\
\hline Consultant & $\begin{array}{l}\text { Provide community opinion to the table; provide resources; provide grounded expertise; } \\
\text { provide experience; bring knowledge; provide information to people and organizations; } \\
\text { give advice and provide insights; act as an advisor; facilitate discussion; provide content } \\
\text { and information }\end{array}$ \\
\hline Funder & $\begin{array}{l}\text { Have discussions with partners from different sectors; use case studies to help partners } \\
\text { develop strategies to educate the partner as well as the public about poverty and how to } \\
\text { take action }\end{array}$ \\
\hline $\begin{array}{l}\text { Oversee the implementation of a case study project: the impacts of precarity on } \\
\text { neighborhoods }\end{array}$ \\
\hline $\begin{array}{l}\text { Provide funding for the research } \\
\text { Monitor }\end{array}$
\end{tabular}

\subsubsection{Advocate}

Four of the 12 interviewees from the nonprofit sector commented on the importance of this role. A quotation from an NGO partner highlights that "I think the most important role for us is raising awareness. We want to make a lot of people aware and want to also hear different voices from newcomers and government. It sounds like a kind of education, but goes beyond that in terms of civil society, to getting people to know that precarious employment really affects the whole economy."

In their view, NGOs' advocacy role positively impacts the lives of their communities and helps develop awareness about the impacts of precarious employment. They are the ones who instill value and mission to the collaborative platform and drive the course forward. They may further "take the findings to the community" and drive impacts by "changing policies and changing practices" (an NGO interview). 


\subsubsection{Initiator}

As an initiator, an NGO draws initial public attention to an important social problem and accords it legitimacy within a stakeholder group. For instance, in 2008, United Way Toronto identified the problem of poverty and employment precarity and strategically initiated a community-university research partnership to solicit help and resources from other organizations to effectively address this complex problem. As one interviewee from the university sector recalled:

We developed together, so it started at the beginning of the project, and a year before, we developed the idea and made the proposal together.

Another interviewee from the non-NGO sector also commented on this NGO role:

The most important role is that they engaged throughout the whole process and did not just participate for a period or at a particular point of time. For example ... they are engaged from initiation to execution. They were really encouraged to start this project and facilitated the whole project from seven years ago.

\subsubsection{Leader}

Four of the 12 interviewees from the NGO sector and two of the four interviewees from other sectors mentioned the significance of this NGO role in the research alliance. For instance, an NGO partner emphasized that:

We co-lead Case Studies 2 and 3 with some researchers from Ryerson University, York University, and the University of Toronto. I think the most important role for us is co-leading the research in this alliance and working on the proposal and report.

A university partner confirmed this role of the NGOs:

... The co-lead on the overall project is the United Way. The United Way certainly has a major voice shaping the overall project and also takes the lead on the policy response.

NGOs are often in an advantageous position to lead collaborative initiatives targeting social change because they have explicit societal goals and strive for public benefits. They are the best actors to lead a CSSP as they have the power and resources to take the initiative to shape the project and ensure the social mission is accomplished.

\subsubsection{Analyst}

Results suggest that NGOs play a diverse range of roles in a CSSP setting, with some roles ranking more significantly than the others, contingent on the goals of the CSSP and their cross-sector partners. As PEPSO is a research-oriented CSSP, 9 of the 12 interviewees from the NGO sector and all the interviewees from other sectors commented on the importance of NGOs playing the role of analyst. For instance, two NGO partners highlighted:

We sat on the community advisory committee and worked on CSSP research, we reviewed the survey questions and brought other sources and information.

-NGO partner, Interview

... We contributed the conceptualization of the project and interpretation of the data. My organization contributes to the overall framing, shaping, and messaging of the report.

-NGO partner, Interview

It is interesting that even a university partner would applaud the effectiveness of the analytic role that the NGOs play in the partnership: 
A number of experts from non-profits are directly involved in the research project. They effectively participate and assist on designing surveys and interpreting findings.

-University partner, Interview

"Analyst" is the most essential role in a research CSSP. In this role, NGOs are deeply involved in the main theme of the CSSP, making massive contributions to shaping and designing the project, overseeing its implementation, contributing at all stages of the research cycle, fostering the effectiveness of the research, and transferring knowledge to action.

\subsubsection{Broker (Bridger)}

Establishing connections with internal and external stakeholders is crucial in a community-university research partnership. Three of the 12 interviewees from the non-profit sector and 1 interviewee from the government sector commented on the significance of an NGO's broker (bridger) role. The NGO partner mentioned:

I think our organization is a valuable partner in part 2 of the case study in terms of reaching out to community members and service providers. We do much to also reach out to people from different sectors in our community.

In this brokering (bridging) role, NGOs reach out to stakeholders (e.g., community and service providers) on both the supply and the demand side to obtain a greater understanding of the needs and resources, so as to connect the dots. A government partner applauded this NGO role:

I know some non-profits also try their best to contact other expertise and researchers in the field to make the whole team become stronger.

Acting as the connecting tissues of an organ, the brokering (bridging) role of NGO hold the coalition together and render the alliance stronger and more stable.

\subsubsection{Communicator}

Two interviewees from the NGO sector commented on this role. For instance, an NGO partner emphasized that "We are working on the key strategic communication and the report findings." In the CSSP setting, partners come from diverse sectors with different interests, missions and value propositions. In a large and diverse CSSP, the communicator role of NGOs is critical. In this role, NGOs build a routine for frequent and smooth connections, interactions, and coordination to ensure the CSSP operates efficiently.

\subsubsection{Consultant}

NGOs can take on the essential role of providing insights and guidance concerning precarity issues to the advisory committee; this role is highly rated by the alliance partners. Seven of the 12 interviewees from non-profit sectors, 2 of the 4 interviewees from the university sector, and 1 interviewee from the government sector commented on the importance of this role. Specifically, an NGO partner commented that:

We bring people and organization information to the committee table. We provide the committee with staff and resources and we also provide our knowledge and expertise of the local context.

Another NGO partner also indicated that he/she "plays the expert advisor role in the project" and that their NGO's "understanding and knowledge on precarious employment bring much insight to the committee." This NGO role is confirmed by an interviewee from a university:

There are two main non-profits that we often contact as consultants. They have provided us with many useful insights about the poverty and precarity in their local community.

Our findings indicate that "consultant" is a common role for NGOs in partnerships and provide knowledge, expertise, and funding that contributes substantially to the research partnership. 


\subsubsection{Capacity Builder}

One interviewee from the non-NGO sector commented on this capacity-builder role, a quotation from an NGO partner emphasizes this role:

I think we play a pivotal role in this research partnership. Around the committee table, we facilitate immediate discussions with people from different sectors. At the local level, our organization uses case studies to develop a strategy to educate other partners and the public about poverty and how to take action.

As a capacity builder, NGOs help to build mature relationships as well as provide training or education opportunities for partners to help develop community capacities.

\subsubsection{Monitor}

An interviewee from the NGO sector commented on this role, which is a newly identified role in this study. Our results suggest NGOs can act as monitors to oversee projects in CSSPs. For instance, a quotation from an NGO partner emphasizes this role: "We oversee Case Study 5-the impacts of precarity on neighborhoods to ensure its compliances with the project goals".

\subsubsection{Funder}

An interviewee from the NGO sector commented on this role. A quotation from an NGO partner emphasized that: "The other role we play is that we provide funding for the research." Funder is an important and new role of NGOs. Normally, NGOs are recipients of public or private funding to finance social change projects. However, large NGOs such as the United Way have diverse and substantial resource channels (e.g., memberships and donations). Thus, they can strategically identify and invest in projects addressing social problems with the potential of generating grand social impacts.

\subsection{Most Valued Roles}

Every interviewee was asked about the most important role of non-profit partners in this community-university research partnership. The interviewees' answers are presented in Table 4 (arranged from the most to the least number of answers on that role). On the basis of the results in Table 4, the three most important roles for NGOs in a research partnership are analyst, consultant, and leader.

Table 4. Most Valued NGO Roles.

\begin{tabular}{cccc}
\hline Roles & $\begin{array}{c}\text { NGO Partner (Number } \\
\text { of Most Valued Roles) }\end{array}$ & $\begin{array}{c}\text { Non-NGO Partner (Number } \\
\text { of Most Valued Roles) }\end{array}$ & Total \\
\hline Number of Interviewees & 12 & 4 & 16 \\
Analyst & 9 & 4 & 13 \\
Consultant & 7 & 2 & 9 \\
Leader & 4 & 2 & 6 \\
Advocate & 4 & 0 & 4 \\
Bridger & 3 & 1 & 4 \\
Initiator & 0 & 3 & 3 \\
Communicator & 2 & 0 & 2 \\
Capacity builder & 0 & 1 & 1 \\
Funder & 1 & 0 & 1 \\
Monitor & 1 & 0 & 1 \\
\hline
\end{tabular}

\section{Discussion}

Table 5 shows that the literature review discussed 10 NGO roles in a community-university partnership. Of these roles, service provider, mediator, convener, and innovator were not mentioned in 
the interviews. Six roles-including capacity builder, consultant, broker (bridger), initiator, advocate, and leader-were validated in the empirical findings. We found four new roles-analyst, funder, communicator, and monitor-in the study case. We confirmed previous scholarship on NGOs' common essential roles in CSSP — such as capacity builder, consultant, broker (bridger), and advocate-which are essential for NGOs in their daily work routines [54]. Specifically, consultant is a key role taken by some NGO partners in the research partnership. For the consultant role, NGOs can bring knowledge and expertise to the table that can broaden and strengthen the partnership.

Table 5. Comparison between NGO Roles in the Literature Review and the Empirical Findings.

\begin{tabular}{|c|c|c|c|}
\hline & Literature Review & Empirical Findings & Comments \\
\hline Enabling Roles & $\begin{array}{l}\text { Service provider } \\
\text { Consultant } \\
\text { Capacity builder }\end{array}$ & $\begin{array}{l}\text { Consultant } \\
\text { Capacity builder } \\
\text { Analyst } \\
\text { Funder }\end{array}$ & $\begin{array}{c}\text { Not found in this context } \\
\text { Validate } \\
\text { Validate } \\
\text { New role } \\
\text { New role }\end{array}$ \\
\hline Coordinating Roles & $\begin{array}{l}\text { Bridger } \\
\text { Mediator }\end{array}$ & $\begin{array}{c}\text { Bridger } \\
\text { Communicator } \\
\text { Monitor }\end{array}$ & $\begin{array}{c}\text { Validate } \\
\text { New role } \\
\text { Not found in this context } \\
\text { New role }\end{array}$ \\
\hline Facilitating Roles & $\begin{array}{l}\text { Convener } \\
\text { Initiator } \\
\text { Advocate } \\
\text { Leader } \\
\text { Innovator }\end{array}$ & $\begin{array}{l}\text { Initiator } \\
\text { Advocate } \\
\text { Leader }\end{array}$ & $\begin{array}{c}\text { Not found in this context } \\
\text { Validate } \\
\text { Validate } \\
\text { Validate } \\
\text { Not found in this context }\end{array}$ \\
\hline
\end{tabular}

Besides the common roles listed in the literature and case study, our empirical findings especially emphasized the new role of analyst. Most NGO partners in the research partnership mentioned the analyst role because they invest much time and energy on writing proposals, designing surveys, interpreting findings, and shaping reports. The research results are essential to these NGOs, because they influence policy agendas by conducting research and helping to produce knowledge and public good [24]. Numerous cross-sectoral social partnerships focus on process outcomes [36], since these are easy to measure, and the collaboration itself is an outcome. At the partnership level, the co-created products are the primary outputs and take up a considerable part of the partners' effort and time. Thus, NGOs in this research partnership strongly emphasize the analyst role that help produce the primary partnership-level output.

We also found a new role of NGOs, the communicator role. This role strongly emphasizes NGOs' capacities as intermediaries [32] to communicate needs, viewpoints, and results across diverse partners, so as to enhance mutual trust, understanding, and goal congruence. This communicator role enables NGOs to better bridge different stakeholders, institutions, and individuals.

Prior CSSP research did not sufficiently discuss the NGOs roles of initiator, funder, and leader, mainly owing to NGOs' resource and power constraints. Our study revealed the significance of these roles for NGOs. Depending on the size and scale of the organizations, some NGOs with abundant resources take the initiative, conduct the research, and act as leaders in the partnership. It is not always the same organization that leads and initiates or there may be additional leaders after initiation, so these roles are distinct.

\section{Conclusions}

In summary, our results advance CSSP scholarship by identifying and empirically testing NGOs' nuanced roles in a CSSP setting that enable, coordinate, and facilitate cross-sector partners for social change. This contributes to a better understanding of the roles of NGOs in helping implement sustainable development goals (SDG) \#17. NGOs play these roles through a CSSP formation and 
implementation process: they initiate a social change project and convene the key stakeholders; they coordinate the diverse interests of different partners to build cohesion and synergy in CSSPs. Through playing the varied roles, they act as a catalyst—an agent that precipitates social change and innovation [24]. They act as change advocates, lobbying for social innovation and change "based on value objectives rather than strict material interests" [33]. The series of roles enable NGOs to instill social value in CSSPs, and to create a vision and facilitate a process to bring the vision to a stage in which it can be implemented [24]. These social-driven and innovative aspects give NGOs a competitive advantage over other organizations [24] in leading a social change process and facilitating the sustainable development of the society.

We found four roles of NGOs (service provider, mediator, convener, and innovator) that are not validated by our interview. These results are mainly due to the context and theme of our study case. First of all, since our selected CSSP is a research-based partnership, service provision is not a primary NGO role in such a CSSP. Further, the convening process may have started before the forming of this CSSP, thus the interviewees may not include or recall the convening role during that period. Similarly, conflicts normally occur in a CSSP where power is unevenly distributed between the business sector and NGOs. Since the business sector is not present in this CSSP, NGOs' mediator role is not so important in this case. In relation to the innovator role, in this research-oriented CSSP, NGOs' role in supporting new product development or new service innovation is not critical.

These findings thus reveal the limitation of our study. We used a single-case design, which is not rich enough to validate all nuanced roles of NGOs in a CSSP setting. We therefore encourage future research to apply multiple cases or a longitudinal design to explore NGO roles and involvements in CSSPs. Studies can also consider using a CSSP case with the involvement of private business sectors and the government sector, which would provide stronger insights about NGOs' roles in CSSPs in a broader context. The adding of additional CSSP cases in different time periods and in different sectors (business and government) would allow more interesting comparative studies of NGOs' roles in CSSP across time, cases, sectors, and geographical settings. In addition, further research could be completed on the interactions of various roles which reveal more insights. From a sustainability perspective, more research could also be done on the impacts of the partnership and if similar partnerships exist in other major urban areas. What difference does the role of various NGOs make to the sustainability progress outcomes?

In conclusion, this research adopted the Poverty and Precarious Employment in Southern Ontario (PEPSO) research partnership as the case study. This empirical study clarifies the significance of NGOs in CSSPs and demonstrates how non-profit partners collaborate with other sectors to render the partnership stability, efficiency, effectiveness in instigating social change. Concerning NGOs' roles in this partnership, besides the common roles, such as advocate, consultant, connector, and capacity builder cited in our literature review, we identified new roles of NGOs such as analyst, communicator, funder, and monitor that enable them to play enabling, coordinating, and facilitating roles in CSSPs for social change. NGOs not only assist in raising greater awareness about employment precarity in Southern Ontario, but also help to educate the public on achieving the goal of sustainable development. NGOs roles in research partnership should be encouraged and supported by all, especially from governments and academic institutions. For local NGOs, funds need to be allocated to them in order for them to proceed with their missions successfully. The public and private sectors should go hand in hand to encourage these NGOs to share their experience and expertise with the public.

Overall, with the spread of CSSPs for dealing with complex social issues, NGOs' contributions and roles will garner more public attention. This paper identifies and addresses NGOs' roles in a specific community-university research partnership. This study has important policy implications. If SDG \#8 is to be realized, cross-sector partnerships which include NGOs are part of the solution. Distinguished from other sectors, NGOs have strong missions to meet social needs and to provide society with public goods [55,56]. It is important to understand the diverse roles NGOs play in these social projects in a CSSP setting, so that NGO managers and policy makers can consider ways to 
continuously support and accelerate NGOs' capacities to innovate and provide better social services in health care, jobs, and homes [56]. The findings are also likely relevant to other large local partnerships such as those focused on sustainable cities [6,57] and on climate action [58].

Acknowledgments: Financial support for this project was provided by the Social Sciences and Humanities Research Council of Canada (SSHRC) Insight Grant (SSHRC \#435-2012-1557 entitled “Cross-Sector Solutions to Complex Environmental Issues").

Author Contributions: Xinya Yan and Haiyng Lin designed the study; Xinya Yan performed the data collection and analyzed the data; Haiying Lin contributed literature review and analysis tools; Xinya Yan wrote the first draft and Haiying Lin significantly improved the paper to the current version. Amelia Clark acted as a second coder and verified the data analysis. She also helped edit the paper.

Conflicts of Interest: The authors declare no conflict of interest.

\section{Appendix A}

\section{Interview Questions for Potential Interviewees: NGO Participants}

Who: Staff members from nonprofit organizations involved in the PEPSO project

How: Per phone (approximately 15 to $30 \mathrm{~min}$ )

Objectives:

This study seeks to identify the roles of nonprofit organizations as partners in a community-university-based research alliance on precarious employment in the Greater Toronto and Hamilton areas. We will also explore the motivations of these nonprofit organizations in the collaboration as well as the challenges these organizations face in the research alliance.

Interview Questions:

1. Kindly briefly describe your role in the organization.

2. What is your role in the PEPSO project?

3. When did your organization become involved in PEPSO research alliance?

4. What drives your organization's involvement in this alliance?

5. In your view, what benefits do your organization gain from participating in this alliance?

6. Which is the most important benefit your organization gets from this alliance?

7. What are your organization's roles in the collaboration?

8. Of these, which is your organization's most important role?

9. In your view, what were your organization's contributions to the research alliance?

10. Of these, what is your organization's most important contribution?

11. Which challenges does your organization face in this alliance?

12. Of these, what is the biggest challenge?

13. What would you like to achieve through your participating in PEPSO project?

14. Is there anyone else I should speak to on this subject?

Thank you!

\section{Appendix B}

\section{Interview Questions for Potential Interviewees: Non-NGO Participants}

Who: Staff members from government and universities involved in the PEPSO project How: Per phone (approximately 15 to $30 \mathrm{~min}$ )

Objectives:

This study seeks to identify the roles of nonprofit organizations as partners in community-university-based research alliance on precarious employment in the Greater Toronto and 
Hamilton areas. We will also explore the motivations of these nonprofit organizations in the collaboration and the challenges these organizations face in the research alliance.

Interview Questions:

1. Kindly briefly describe your role in the organization.

2. What is your role in the PEPSO project?

3. In your view, what drives nonprofit organizations to become involved in PEPSO?

4. What benefits do these nonprofit partners get from participating in PEPSO?

5. What is the most important benefit they get?

6. In your view, what roles do these nonprofit partners take in this collaboration?

7. Of these, which is the most important role?

8. What contributions do these nonprofit partners make to PEPSO?

9. Of these contributions, which is the most important one?

10. What challenges do these nonprofit partners face in this CSSP?

11. Of these, which is the biggest challenge for them?

12. What would they like to achieve by participating in PEPSO?

13. Is there anyone else I should speak to on this subject?

Thank you!

\section{References}

1. George, G.; Howard-Grenville, J.; Joshi, A.; Tihanyi, L. Understanding and Tackling Societal Grand Challenges through Management Research. Acad. Manag. J. 2016, 59, 1880-1895. [CrossRef]

2. Lin, H.; Darnall, N. Strategic Alliances for Environmental Protection. In Facilitating Sustainable Innovation through Collaboration: A Multistakeholder Perspective; Sarkis, J., Cordeiro, J., Vazquez Brust, D., Eds.; Springer: New York, NY, USA, 2010; pp. 233-246.

3. Clarke, A. Designing Social Partnerships for Local Sustainability Strategy Implementation. In Social Partnerships and Responsible Business: A Research Handbook; Seitanidi, M., Crane, A., Eds.; Routledge: London, UK, 2014.

4. Gray, B. Conditions Facilitating Interorganizational Collaboration. Hum. Relat. 1985, 38, 911-936. [CrossRef]

5. Lin, H. Cross-Sector Alliances for Corporate Social Responsibility: Partner Heterogeneity Moderates Environmental Strategy Outcomes. J. Bus. Ethics 2012, 12, 13-25. [CrossRef]

6. MacDonald, A.; Clarke, A.; Huang, L.; Roseland, M.; Seitanidi, M.M. Cross-Sector Partnerships (SDG \#17) as a Means of Achieving Sustainable Communities and Cities (SDG \#11). In Handbook of Sustainability Science and Research; Leal Filho, W., Ed.; Springer Publishing Company: New York, NY, USA, 2018.

7. United Nations. Sustainable Development Goals. 2015. Available online: https://sustainabledevelopment. un.org/sdgs (accessed on 14 February 2018).

8. Lempert, D.; Nguyen, H.N. A Sustainable Development Indicator for NGOs and International Organisations. Int. J. Sustain. Soc. 2008, 1, 15-44. [CrossRef]

9. Gladwin, T.M.; Kennelly, J.; Krause, T. Shifting paradigms for sustainable development: implications for management theory and research. Acad. Manag. Rev. 1995, 20, 874-907.

10. Deakin, M.; Allwinkle, S. Urban Regeneration and Sustainable Communities: The Role of Networks, Innovation, and Creativity in Building Successful Partnerships. J. Urban Technol. 2007, 14, 77-91. [CrossRef]

11. Cranford, C.; Vosko, L.; Zukewich, N. Precarious Employment in the Canadian Labour Market: A Statistical Portrait. Just Labour 2003, 3, 6-22.

12. Clarke, M.; Lewchuk, W.; Wolff, A.D.; King, A. 'This Just isn't Sustainable': Precarious Employment, Stress and Workers' Health. Int. J. Law Psychiatry 2007, 30, 311-326. [CrossRef] [PubMed]

13. Brown, L.D.; Khagram, S.; Moore, M.H.; Frumkin, P. Globalization, NGOs, and Multi-Sectoral Relations; Working Paper; The Hauser Center for Nonprofit Organizations and The Keynedy School of Government, Harvard University: Cambridge, MA, USA, 2000. 
14. Young, D. Nonprofits and government: Collaboration and Conflict. In Complementary, Supplementary, or Adversarial? A Theoretical and Historical Examination of Nonprofit Government Relations in the United States; Urban Institute Press: Washington, DC, USA, 1999; pp. 31-67.

15. Brinkerhoff, J.M. Government-Nonprofit partnership: A Defining Framework. Public Adm. Dev. 2002, 22, 19-30. [CrossRef]

16. Gazley, B.; Brudney, J.L. The Purpose (and Perils) of Government-Nonprofit partnership. Nonprofit Volunt. Sect. Q. 2007, 36, 389-415. [CrossRef]

17. Rühli, E.; Sachs, S.; Schmitt, R.; Schneider, T. Stakeholder Engagement: Clinical Research Cases. Issues in Business Ethics. In Innovation in Multistakeholder Settings: The Case of a Wicked Issue in Health Care; Freeman, R., Kujala, J., Sachs, S., Eds.; Springer: Cham, Switzerland, 2017; Volume 46, pp. 255-282.

18. Austin, J.E. The Collaboration Challenge: How Nonprofits and Businesses Succeed through Strategic Alliances; Jossey-Bass Publishers: San Francisco, CA, USA, 2000.

19. Kong, N.; Salzmann, O.; Steger, U.; Somers, A. Moving Business/Industry towards Sustainable Consumption: The Role of NGOs. Eur. Manag. J. 2002, 20, 109-127. [CrossRef]

20. Wellesley Institute. Collaboration in the Third Sector: From Co-Operation to Impact Driven Cooperation; Working Paper; Wellesley Institute: Toronto, ON, Canada, 2008.

21. Yin, R.K. Case Study Research and Applications: Design and Methods, 6th ed.; SAGE Publications: Thousand Oaks, CA, USA, 2017.

22. Young, S.T.; Dhanda, K.K. Chapter 9: Role of Governments and Nongovernmental Organizations. In Sustainability: Essentials for Business; SAGE: Thosand Oaks, CA, USA, 2013; pp. 214-241.

23. Canadian Business for Social Responsibility (CBSR). Partnering for Innovation-Driving Change through Business/NGO Partnerships; Official Report; Canadian Business for Social Responsibility: Hongkong, 2005.

24. Lewis, D.; Kanji, N. Non-Governmental Organizations and Development; Routledge: London, UK, 2009.

25. Nikkhah, H.; Redzuan, M. The Role of NGOs in Promoting Empowerment for Sustainable Community Development. J. Hum. Ecol. 2010, 30, 85-92. [CrossRef]

26. Rekha, M. Credit for Women: Why Is It so Important? Working Paper; International Research and Training Institute for the Advancement of Women: Bengaluru, India, 1997.

27. Stadtler, L.; Probst, G. How broker organizations can facilitate public-private partnerships for development. Eur. Manag. J. 2012, 30, 32-46. [CrossRef]

28. Stephan, U.; Patterson, M.; Kelly, C.; Mair, J. Organizations driving positive social change: A review and an integrative framework of change processes. J. Manag. 2016, 42, 1250-1281. [CrossRef]

29. Brown, L.D. Bridging Organizations and Sustainable Development. Hum. Relat. 1991, 44, 807-831. [CrossRef]

30. Stafford, E.R.; Polonsky, M.J.; Hartman, C.L. Environmental NGO-Business Collaboration and Strategic Bridging: A Case Analysis of the Greenpeace-Foron Alliance. Bus. Strategy Environ. 2000, 9, 122-135. [CrossRef]

31. Westley, F.; Vredenburg, H. Strategic Bridging: The Collaboration between Environmentalists and Business in the Marketing of Green Products. J. Appl. Behav. Sci. 1991, 27, 65-90. [CrossRef]

32. Montgomery, A.W.; Dacin, P.A.; Dacin, M.T. Collective Social Entrepreneurship: Collaborative Shaping Social Good. J. Bus. Ethics 2012, 11, 375-388. [CrossRef]

33. Wade-Benzoni, K.A.; Hoffman, A.; Thompson, L.; Moore, D.; Gillespie, J.; Bazerman, M. Barriers to resolutions in ideologically based negotiations: The role of values and institutions. Acad. Manag. Rev. 2002, 27, 41-57.

34. Martin, N. "There Is Abuse Everywhere": Migrant Nonprofit Organizations and the Problem of Precarious Work. Urban Aff. Rev. 2012, 48, 389-416. [CrossRef]

35. Sharma, S.; Vredenburg, H.; Westley, F. Strategic Bridging: A Role for the Multinational Cooperation in Third World Development. J. Appl. Behav. Sci. 1994, 30, 458-476. [CrossRef]

36. Clarke, A.; Fuller, M. Collaborative Strategic Management: Strategy Formulation and Implementation by Multi-Organizational Cross-Sector Social Partnerships. J. Bus. Ethics 2010, 94 (Suppl. 1), 85-101. [CrossRef]

37. Dorado, S.; Vaz, P. Conveners as champions of collaboration in the public sector: A case from South Africa. Public Adm. Dev. 2003, 23, 141-150. [CrossRef]

38. Najam, A. Citizen Organizations as Policy Entrepreneurs. In International Perspectives on Voluntary Action: Reshaping the Third Sector; Earthscan: London, UK, 1999; pp. 142-148. 
39. Najam, A. Nongovernmental Organizations as Policy Entrepreneurs: In Pursuit of Sustainable Development; Working Paper; Yale University: London, UK, 1996.

40. Edwards, M. 'Does the Doormat Influence the Boot?' Critical Thoughts on UK NGOs and International Advocacy. Dev. Pract. 1993, 3, 163-175. [CrossRef]

41. Choup, A.M. Catalysts for Cooperation: Non-Governmental Organizations in Santo Domingo. J. Civ. Soc. 2006, 2, 217-231. [CrossRef]

42. Kourula, A.; Laasonen, S. Nongovernmental Organizations in Business and Society, Management, and International Business Research: Review and Implications From 1998 to 2007. Bus. Soc. 2010, 49, 35-67. [CrossRef]

43. Svendsen, A.C.; Laberge, M. Convening stakeholder networks. J. Corp. Citizsh. 2005, 19, 91-104. [CrossRef]

44. Precarious Employment Rising in GTA \& Hamilton. It Raises Questions about Our Ability to Sustain Households, to Have Families. 2013. Available online: www.cbc.ca/news/canada/toronto/precariousemployment-rising-in-gta-hamilton-1.1384802 (accessed on 14 February 2018).

45. McMaster University-United Way Toronto. It's More than Poverty: Precarious Work and Household Well-Being. Poverty and Employment Precarity in Southern Ontario; Working Paper; McMaster University-United Way Toronto: Toronto, ON, Canada, 2013.

46. Vosko, L.F.; Zukewich, N.; Cranford, C. Precarious Jobs: A New Typology of Employment. In Perspectives on Labour and Income; Volume 4, Available online: http:/ / www.statcan.gc.ca/pub/75-001-x/01003/6642-eng. html (accessed on 14 February 2018).

47. Poverty and Employment Precarity in Southern Ontario (PEPSO). Available online: https:/ / pepsouwt.files. wordpress.com/ (accessed on 14 February 2018).

48. McMaster University and United Way Toronto. Poverty and Employment Precarity in Southern Ontario (PEPSO). Available online: http:/ / pepso.ca/2012/12/08/hello-world/ (accessed on 14 February 2018).

49. Lévesque, B.; Mendell, M. The Social Economy: Approaches, Practices and a Proposal for a New Community-University Alliance (CURA). J. Rural Coop. 2005, 33, 21-45.

50. Social Sciences and Humanities Research Council. Available online: www.sshrc-crsh.gc.ca/fundingfinancement/programs-programmes / community-universityresearchpartnership-aruc-eng.aspx\#archived (accessed on 14 February 2018).

51. McMaster University and United Way Toronto. 'It's More Than Poverty: Employment Precarity and Household Well-Being' PEPSO (Poverty and Employment Precarity in Southern Ontario). Available online: http:/ / pepso.ca/2012/12/05/policy-forum/ (accessed on 14 February 2018).

52. Bryman, A.; Bell, E. Social Research Methods: Third Canadian Edition; Oxford University Press: Oxford, UK, 2012.

53. Flick, U. An Introduction to Qualitative Research, 3rd ed.; SAGE Publications: London, UK, 2006.

54. Stadtler, L. Designing Public-Private Partnerships for Development. Management 2012, 15, 78-100. [CrossRef]

55. Murray, R.; Grice, J.; Mulgan, G. The Open Book of Social Innovation; Then Young Foundation: London, UK, 2010; pp. 20-220.

56. Mulgan, G. The Process of Social Innovation; Springer: New York, NY, USA, 2006; pp. 145-162.

57. Clarke, A.; MacDonald, A. Outcomes to Partners in Multi-Stakeholder Cross-Sector Partnerships: A Resource-Based View. Bus. Soc. 2016. [CrossRef]

58. Clarke, A.; Ordonez-Ponce, E. City Scale: Cross-Sector Partnerships for Implementing Local Climate Mitigation Plans. Special Blog Issue: Climate Change and Public Administration. Public Administration Review. Available online: https://publicadministrationreview.org/climate-change-symposium-crosssector-partnerships/ (accessed on 14 February 2018).

(C) 2018 by the authors. Licensee MDPI, Basel, Switzerland. This article is an open access article distributed under the terms and conditions of the Creative Commons Attribution (CC BY) license (http:/ / creativecommons.org/licenses/by/4.0/). 